\title{
Effects of Treated Sugar Mill Effluent Irrigation on Soil and Hybrid Cultivar of Eggplant (Solanum melongena L.) under Field Conditions
}

\author{
Vinod Kumar*
}

Agro-ecology and Pollution Research Laboratory, Department of Zoology and Environmental Science, Gurukula Kangri University, Uttarakhand, India

*Corresponding author: Kumar, V. Agro-ecology and Pollution Research Laboratory, Department of Zoology and Environmental Science, Gurukula Kangri University, Haridwar-249404 (Uttarakhand), India E-mail: drvksorwal@gkv.ac.in

\begin{abstract}
The disposal of sugar mill effluent is a major problem in India due to generation of huge quantity of effluent in the sugar mills. The present investigation was conducted to study the effects of sugar mill effluent as an alternative of synthetic fertilizers. Six plots were selected for six treatments of sugar mill effluent viz. $0 \%$ (control), $20 \%$, $40 \%, 60 \%, 80 \%$ and $100 \%$ for irrigation of Solanum melongena L., cv. Pusa Purple Long Hybrid- $\mathrm{F}_{1}$. The $S$. melongena was grown in sugar mill effluent irrigated soil till harvest and effects of sugar mill effluent on the soil and agronomical characteristics of $S$. melongena were analyzed. The concentrations of sugar mill effluent produced significant $(\mathrm{P}<0.05 / \mathrm{P}<0.01)$ changes in $\mathrm{EC}, \mathrm{pH}, \mathrm{OC}, \mathrm{Na}^{+}, \mathrm{K}^{+}, \mathrm{Ca}^{2+}, \mathrm{Mg}^{2+}, \mathrm{TKN}, \mathrm{PO}_{4}^{3-}$, $\mathrm{SO}_{4}^{2-}, \mathrm{Cd}, \mathrm{Cr}, \mathrm{Cu}, \mathrm{Fe}, \mathrm{Mn}$ and $\mathrm{Zn}$ of the soil in both seasons. The agronomic performance of $S$. melongena was increased from 20 to $60 \%$ concentrations of the sugar mill effluent in both the seasons compared to controls. The accumulation of heavy metals was increased in the soil and S. melongena from 20 to $100 \%$ concentrations of the sugar mill effluent in both seasons. The biochemical components like crude proteins, dietary fiber, total carbohydrates and total sugar in $S$. melongena were found maximum with $60 \%$ concentration of the sugar mill effluent in both seasons. The contamination factor (Cf) of various metals were in the order of $\mathrm{Zn}>\mathrm{Mn}>\mathrm{Cd}>\mathrm{Cu}>\mathrm{Fe}>\mathrm{Cr}$ for the soil and $\mathrm{Fe}>\mathrm{Mn}>\mathrm{Cu}>\mathrm{Zn}>\mathrm{Cd}>\mathrm{Cr}$ for $S$. melongena in both seasons after irrigation with sugar mill effluent. Thus, sugar mill effluent irrigation increased nutrients in the soil and affected the growth of $S$. melongena in both seasons. Consequently, it can be used for irrigation in the lower proportion (up to $60 \%$ ) to improve the yield of $S$. melongena.
\end{abstract}

Received date: July 07, 2015

Accepted date: December 16, 2015

Published date: December 22, 2015

Citation: Kumar, V. Effects of Treated Sugar Mill Effluent Irrigation on Soil and Hybrid Cultivar of Eggplant (Solanum melongena L.) under Field Conditions. (2015) J Environ Health Sci 1(4): 1-11.

DOI: $10.15436 / 2378-6841.15 .021$

Keywords: Heavy metals; Irrigation; Rainy and summer season; Solanum melongena; Sugar mill effluent

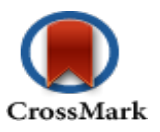

\section{Introduction}

India is being one of the largest producers of sugar in the world and presently has nearly 650 sugar mills that produce about 15 million tons of sugar and 13 million tons of molasses (spent wash) per year ${ }^{[1-3]}$. The sugar mill effluent is mainly discharged from floor, waste water and condensate water formed by leakage. The disposal of polluted waste water is one of the main problems of today to be faced in the future with its increased adverse effects ${ }^{[4-7]}$. Most of the sugar mills are discharging their effluent into the environment without any treatment. It has also been reported that sugar mill effluent contains a high magnitude of pollution load and caused adverse effects on soil and biological system. The effluent constitute a number of physico-chemical elements of suspended and dissolved solids with the high amount of biological oxygen demand (BOD), chemical oxygen demand (COD), chlorides, sulphate, nitrates, calcium, magnesium and metals ${ }^{[8-10]}$.

In addition to that, some traceable amount of heavy metals such as zinc, copper and lead are usually present in the sugar mill effluent. The presence of these chemicals in large quantities in the effluent not only affects plant growth but also collapses the soil properties when used for irrigation ${ }^{[3,5,8]}$. Therefore, the effluent can be applied to productive uses since it contains nutrients that have the potential for use in agriculture. In agriculture, irrigation water can affect soil characteristics, and agricultural crop growth. Besides this use of effluent reduces fertilizer, and irrigation water cost as it is available without paying any cost and rich in various plant nutrients ${ }^{[5,7,9]}$. Wastewater irrigation is known to contribute significantly to the heavy metal content of the soils. The heavy 
metals may also accumulate in the soil at toxic levels as a result of long-term application of untreated wastewaters. They are considered as soil contaminants due to their widespread occurrence, acute and chronic toxicity ${ }^{[10,12]}$.

After long-term application of untreated wastewaters, significant amounts of heavy metals can accumulate in the soil at toxic levels. At present, heavy metals, such as cadmium $(\mathrm{Cd})$, chromium $(\mathrm{Cr})$, copper $(\mathrm{Cu})$, manganese $(\mathrm{Mn})$, lead $(\mathrm{Pb})$, zinc $(\mathrm{Zn})$, etc., are commonly found in subsurface soil irrigated with wastewater $^{[13,14]}$. Once the adsorption sites of the soil for heavy metals are saturated, more heavy metals would be distributed in the aqueous phase and the bioavailability of heavy metals would subsequently be enhanced ${ }^{[15-18]}$. The accumulation of heavy metals in agricultural soils has been a wide concern of the public as well as governmental agencies, due to the food safety issues and potential health risks as well as its detrimental effects on soil ecosystems. In addition, heavy metals pollution has frequently been reported in many contaminated sites ${ }^{[19-21]}$.

Agriculture sector in India has been considered for the major user of water. In the changing scenario, reuse of domestic and industrial wastewater in agriculture for irrigating crops appears to be a beneficial option. Besides being source of irrigation water, these wastewaters contain appreciable amounts of plant nutrients ${ }^{[22-25]}$. The use of industrial effluents for irrigating agricultural lands is on the rise especially in the peri-urban area. These wastewaters carry appreciable amounts of trace toxic metals ${ }^{[10,18,22]}$. Although the concentrations of heavy metals in the effluents are low, long-term use of these wastewaters on agricultural lands often results in the build-up of the elevated levels of these metals in soils and crops ${ }^{[14,20,23]}$.

Additionally, industrial effluent is an important source of irrigation water and plant nutrients such as nitrogen $\mathrm{N}, \mathrm{P}, \mathrm{K}$ and trace elements like $\mathrm{Na}, \mathrm{Ca}$ and $\mathrm{Mg}$. Effluent irrigation can eradicate water shortage; reduce the need for chemical fertilizer and enhance the soil fertility ${ }^{[2-28]}$. However, unregulated irrigation with untreated effluent poses serious public health risks, as effluent is a major source of heavy metals that cause accumulation in plant parts. The effluent contains heavy metals such as $\mathrm{Cd}, \mathrm{Cr}$, nickel (Ni) $\mathrm{Cu}, \mathrm{Fe}$ and $\mathrm{Zn}$ which accumulates in plant and vegetable parts, and cause adverse health effects ${ }^{[16,29-31]}$.

Eggplant (Solanum melongena L.) is identified as one of the most valuable veggies packed with essential nutrients ${ }^{[31,32]}$. The eggplant is a delicate, tropical perennial often cultivated as a tender or half-hardy annual in temperate climates ${ }^{[33]}$. It is being widely cultivated throughout the world in tropical and subtropical climates. Nutritionally, eggplant is low in fat, protein, and carbohydrates. It is rich in dietary fiber, sugar, sodium and potassium $^{[34]}$. It also contains important vitamins like A, B6, C, $\mathrm{D}$ and calcium, iron and magnesium. Eggplant is used in the cuisine of many countries ${ }^{[33-35]}$. It is widely used in its native Indian cuisine, like vegetable, chutney, curry, and pickle. Eggplant, due to its texture and bulk, can be used as a meat substitute in vegan and vegetarian cuisine. The juice of eggplant significantly reduces weight, plasma cholesterol levels, and aortic cholesterol content ${ }^{[32,35]}$.

Recently most studies were conducted on few agronomic stages with limited parameters in various crops, but there are few reports on comprehensive agronomic studies at various agronomic stages of these plants ${ }^{[36-42]}$. Use of industrial effluents on cultivation of $S$. melongena is receiving attention but additional information is required on how this crop responds to various concentrations of different types of effluents ${ }^{[43-47]}$. Keeping in view the significance of sugar mill effluent in the present scenario of agriculture and availability of nutrients, this investigation was conducted to study the effects of sugar mill effluent on the agronomical characteristics of eggplant (Solanum melongena $\mathrm{L}$.) under field conditions.

\section{Materials and Methods}

\section{Experimental design}

The field trials were conducted in the Experimental Garden of the Department of Zoology and Environmental Sciences, Gurukula Kangri University Haridwar, India (29 $55^{\prime} 10.81^{\prime \prime}$ $\mathrm{N}$ and $78^{\circ} 07^{\prime} 08.12^{\prime \prime} \mathrm{E}$ ), to study the agronomical performance of $S$. melongena grown in sugar mill effluent irrigated soil. The crops were cultivated in the rainy and summer seasons during the year 2012 and 2013. For the cultivation of $S$. melongena, six plots (each plot had an area of $9 \times 9 \mathrm{~m}^{2}$ ) were selected for the six treatments of sugar mill effluent viz., $0 \%$ (Bore well water), $20 \%$ (20\% sugar mill effluent $+80 \%$ bore well water), $40 \%(40 \%$ sugar mill effluent $+60 \%$ bore well water), $60 \%$ (60\% sugar mill effluent $+40 \%$ bore well water), $80 \%$ ( $80 \%$ sugar mill effluent + $20 \%$ bore well water) and $100 \%$ (100\% sugar mill effluent). All the six treatments were placed within each of the six plots in a randomized complete block design.

\section{Collection of sugar mill effluent and analysis}

The sugar mill effluent samples were collected from effluent treatment plant of the R.B.N.S. Sugar Mill, Laksar, Haridwar (2944'46"N 78¹'46"E). The sugar mill effluent was collected in the plastic containers from effluent treatment plant located in the campus of the sugar mill. It was brought to the laboratory and analyzed for total dissolved solids (TDS), $\mathrm{pH}$, electrical conductivity (EC), $\mathrm{Na}^{+}, \mathrm{K}^{+}, \mathrm{Ca}^{2+}, \mathrm{Mg}^{2+}$, total Kjeldahl nitrogen (TKN), phosphate $\left(\mathrm{PO}_{4}{ }^{3-}\right)$, sulphate $\left(\mathrm{SO}_{4}{ }^{2-}\right), \mathrm{Cd}, \mathrm{Cr}, \mathrm{Cu}$, $\mathrm{Fe}, \mathrm{Mn}, \mathrm{Zn}$, standard plate count (SPC) and most probable number (MPN) following standard methods ${ }^{[49,50]}$ and used for irrigation of $S$. melongena.

\section{Preparation of nursery of $\boldsymbol{S}$. melongena}

Seeds of a high yield variety of $S$. melongena, cv. Pusa Purple Long Hybrid-F $F_{1}$, were procured from Indian Council of Agriculture Research (ICAR), Pusa, New Delhi, and sterilized with $0.01 \%$ Thiram. The nursery was prepared before one month of transplantation of $S$. melongena in each season. For the nursery preparation $0.6 \mathrm{~g}$ seeds of eggplant were sown in the six plots in the rows $5 \mathrm{~cm}$ apart on 6-12 $\mathrm{mm}$ raised nursery beds (farm yard manure mixed soil). The nursery bed was covered with plastic or straw mulch till seeds germinate ${ }^{[51,52]}$. The plants were irrigated with sugar mill effluent concentrations as per requirement and other agronomical practices like weeding and hoeing were performed till the plants were transplanted in the field.

\section{Transplantation and cultivation practices of $S$. melongena}

Four weeks old plants of $S$. melongena were planted at the end of July 2012 and 2013 for the rainy season crop and at the end of April 2012 and 2013 for the summer season crop. Plants of $S$. melongena were transplanted in 6 rows with a dis- 
tance of $60 \times 60 \mathrm{~cm}$ between plants ${ }^{[51,52]}$. The plants in each plot were irrigated twice in a month with 100 gallons of sugar mill effluent concentrations along with bore well water (control) and necessary agronomical practices were performed till the harvest. The soil was analyzed prior to planting and after harvest for various physico-chemical parameters like soil texture, bulk density (BD), water holding capacity (WHC), $\mathrm{EC}, \mathrm{pH}, \mathrm{OC}, \mathrm{Na}^{+}$, $\mathrm{K}^{+}, \mathrm{Ca}^{2+}, \mathrm{Mg}^{2+}, \mathrm{PO}_{4}^{3-}, \mathrm{SO}_{4}^{2-}, \mathrm{TKN}, \mathrm{Cd}, \mathrm{Cr}, \mathrm{Cu}, \mathrm{Fe}, \mathrm{Mn}$ and $\mathrm{Zn}$ determined following standard methods ${ }^{[50]}$.

\section{Study of crop parameters}

The agronomic parameters of $S$. melongena at different stages (0-110 days) were determined following standard methods for seed germination, plant height, root length, dry weight, chlorophyll content, leaf area index (LAI) and crop yield ${ }^{[54,55]}$. The biochemical parameters like crude protein, dietary fiber, total carbohydrate and total sugar in $S$. melongena were determined following standard methods ${ }^{[51]}$.

\section{Extraction of heavy metals and their analysis}

For the heavy metals analysis $10 \mathrm{ml}$ of sugar mill effluent, $1.0 \mathrm{~g}$ of air dried soil or plants were taken in digestion tubes separately. For each sample $3 \mathrm{ml}$ of concentrate $\mathrm{HNO}_{3}$ was added and digested in an electrically heated block for 1 hour at $145^{\circ} \mathrm{C}$. To this mixture $4 \mathrm{ml}$ of $\mathrm{HClO}_{4}$ was added and heated to $240^{\circ} \mathrm{C}$ for 1 hour. The mixture was cooled and filtered through Whatman \# 42 filter paper. The volume was made to $50 \mathrm{ml}$ by adding double distilled water and used for analysis. Metals were analyzed using an atomic absorption spectrophotometer (PerkinElmer, Analyst 800 AAS, GenTech Scientific Inc., Arcade, NY) following methods ${ }^{[51]}$. In this field study, the contamination fac- tor (Cf) was used to determine the contamination of metals in the soil and $S$. melongena irrigated with sugar mill effluent. The $\mathrm{Cf}$ was calculated following formula ${ }^{[51,54]}$.

\section{Data analysis}

Data were analyzed with SPSS (ver. 14.0, SPSS Inc., Chicago, Ill.). Data were subjected to one-way analysis of variance (ANOVA). Mean standard deviation and coefficient of correlation (r-value) of soil and crop parameters with sugar mill effluent concentrations were calculated with MS Excel (ver. 2013, Microsoft Redmond Campus, Redmond, WA) and graphs produced with Sigma plot (ver. 12.3, Systat Software, Inc., Chicago, IL).

\section{Results and Discussion}

\section{Characteristics of sugar mill effluent}

The physico-chemical and microbiological characteristics of the sugar mill effluent are presented in table 1. The ANOVA analysis of data showed that the values of effluent parameters were found to be significantly $(\mathrm{P}<0.05 / \mathrm{P}<0.01)$ different over the concentrations of sugar mill effluent. The most values of TDS, $\mathrm{EC}, \mathrm{Na}^{+}, \mathrm{K}^{+}, \mathrm{Ca}^{2+}, \mathrm{Mg}^{2+}, \mathrm{PO}_{4}^{3-}, \mathrm{SO}_{4}^{2}, \mathrm{TKN}, \mathrm{Cd}, \mathrm{Cr}, \mathrm{Cu}, \mathrm{Fe}, \mathrm{Mn}$, $\mathrm{Zn}, \mathrm{SPC}$ and MPN of the sugar mill effluent were recorded with absolute (100\% concentration) sugar mill effluent. The sugar mill effluent was highly alkaline ( $\mathrm{pH} 8.80)$. The alkaline nature of the sugar mill effluent might be due to the more contents of alkalis used in the sugar manufacturing process. The higher value of EC $\left(6.20 \mathrm{dS} \mathrm{cm}^{-1}\right)$ in the sugar mill effluent is might be due to more ionic species like $\mathrm{Na}^{+}\left(140.40 \mathrm{mg} \mathrm{L}^{-1}\right), \mathrm{K}^{+}(260.45 \mathrm{mg}$ $\left.\mathrm{L}^{-1}\right), \mathrm{Ca}^{2+}\left(624.60 \mathrm{mg} \mathrm{L}^{-1}\right), \mathrm{Mg}^{2+}\left(190.70 \mathrm{mg} \mathrm{L}^{-1}\right), \mathrm{PO}_{4}^{3-}(110.45$

Table 1: Physico-chemical and microbiological characteristics of sugar mill effluent.

\begin{tabular}{|c|c|c|c|c|c|c|c|}
\hline \multirow{2}{*}{ Parameter } & \multirow{2}{*}{0 (Bore well water) } & \multicolumn{5}{|c|}{ Sugar mill effluent concentration (\%) } & \multirow{2}{*}{$\begin{array}{c}\text { BIS for irrigation } \\
\text { water }\end{array}$} \\
\hline & & 20 & 40 & 60 & 80 & 100 & \\
\hline TDS (mg L-1) & 240.50 & $298.70^{*}$ & $604.20^{* *}$ & $897.80^{* * *}$ & $1140.34^{* * *}$ & $1520^{* * * *}$ & 1900 \\
\hline $\mathrm{EC}\left(\mathrm{dS} \mathrm{cm} \mathrm{cm}^{-1}\right)$ & 0.10 & $1.26^{*}$ & $2.52^{*}$ & $3.78^{* *}$ & $5.10^{* *}$ & $6.20^{* * *}$ & -- \\
\hline $\mathrm{pH}$ & 7.16 & $7.24 \mathrm{~ns}$ & $7.36 \mathrm{~ns}$ & $7.45 \mathrm{~ns}$ & $8.42 \mathrm{~ns}$ & $8.80 \mathrm{~ns}$ & $5.0-9.0$ \\
\hline $\mathrm{BOD}\left(\mathrm{mg} \mathrm{L}^{-1}\right)$ & 5.10 & $78.56^{*}$ & $140.30^{* *}$ & $334.87^{* *}$ & $650.80^{* *}$ & $960.88^{* * *}$ & 100 \\
\hline $\mathrm{COD}\left(\mathrm{mg} \mathrm{L}^{-1}\right)$ & 10.77 & $154.80^{*}$ & $296.50^{* *}$ & $740.78^{* *}$ & $1478.50^{* *}$ & $1670.20^{* * *}$ & 250 \\
\hline $\mathrm{Na}^{+}\left(\mathrm{mg} \mathrm{L}^{-1}\right)$ & 12.45 & $28.20 *$ & $57.10^{*}$ & $86.65^{* *}$ & $120.44^{* *}$ & $140.40^{* * *}$ & -- \\
\hline $\mathrm{K}^{+}\left(\mathrm{mg} \mathrm{L}^{-1}\right)$ & 20.50 & $48.30^{*}$ & $98.40^{*}$ & $148.86^{* *}$ & $196.20^{* *}$ & $260.45^{* * *}$ & -- \\
\hline $\mathrm{Ca}^{2+}\left(\mathrm{mg} \mathrm{L}^{-1}\right)$ & 40.10 & 120.50 & $240.20^{*}$ & $362.97^{* *}$ & $485.90^{* *}$ & $624.60^{* * *}$ & 200 \\
\hline $\mathrm{Mg}^{2+}\left(\mathrm{mg} \mathrm{L}^{-1}\right)$ & 16.40 & $35.80^{*}$ & $72.60^{*}$ & $105.80^{* *}$ & $150.12^{* *}$ & $190.70^{* * *}$ & -- \\
\hline TKN (mg L-1) & 25.60 & $32.45^{*}$ & $45.80^{*}$ & $78.96^{* *}$ & $126.34^{* *}$ & $172.60^{* * *}$ & 100 \\
\hline $\mathrm{PO}_{4}^{3-}\left(\mathrm{mg} \mathrm{L}^{-1}\right)$ & 0.06 & $16.50^{*}$ & $34.12^{*}$ & $52.66^{* *}$ & $90.34^{* *}$ & $110.45^{* * *}$ & -- \\
\hline $\mathrm{SO}_{4}^{2-}\left(\mathrm{mg} \mathrm{L}^{-1}\right)$ & 80.75 & 110.24* & $225.90^{*}$ & $336.78^{* *}$ & $454.70^{* *}$ & $575.90^{* * *}$ & 600 \\
\hline $\mathrm{Fe}\left(\mathrm{mg} \mathrm{L}^{-1}\right)$ & 2.34 & $3.70^{*}$ & $7.14^{*}$ & $12.20^{* *}$ & $15.80^{* *}$ & $20.44^{* * *}$ & 15.00 \\
\hline $\mathrm{Cd}\left(\mathrm{mg} \mathrm{L}^{-1}\right)$ & 0.08 & $1.45^{* *}$ & $2.90^{* *}$ & $4.38^{* *}$ & $5.86^{* *}$ & $8.34^{* * *}$ & 1.00 \\
\hline $\mathrm{Cr}\left(\mathrm{mg} \mathrm{L}^{-1}\right)$ & 0.01 & $0.25^{*}$ & $0.52^{* *}$ & $0.76^{* *}$ & $1.23^{* *}$ & $1.56^{* * *}$ & 2.00 \\
\hline $\mathrm{Cu}\left(\mathrm{mg} \mathrm{L}^{-1}\right)$ & 1.38 & $1.64 *$ & $3.18^{*}$ & $4.84^{* *}$ & $6.38^{* *}$ & $8.24^{* * *}$ & 3.00 \\
\hline $\operatorname{Mn}\left(\mathrm{mg} \mathrm{L}^{-1}\right)$ & 1.12 & $1.25 *$ & $2.56^{*}$ & $3.79^{* *}$ & $5.18^{* *}$ & $6.88^{* * *}$ & 1.00 \\
\hline $\mathrm{Zn}\left(\mathrm{mg} \mathrm{L}^{-1}\right)$ & 1.68 & $1.98^{*}$ & $4.37^{*}$ & $6.78^{* *}$ & $8.88^{* *}$ & $12.23^{* * *}$ & 2.00 \\
\hline $\mathrm{SPC}\left(\mathrm{SPC} \mathrm{ml} \mathrm{ml}^{-1}\right)$ & $3.97 \times 10^{3}$ & $6.90 \times 10^{6 * *}$ & $7.25 \times 10^{8 * *}$ & $5.93 \times 10^{10^{* * *}}$ & $6.88 \times 10^{12^{* * *}}$ & $9.23 \times 10^{14 * * *}$ & 10000 \\
\hline MPN(MPN100 $\left.\mathrm{ml}^{-1}\right)$ & $2.32 \times 10^{2}$ & $4.78 \times 10^{4 * *}$ & $8.56 \times 10^{6 * *}$ & $3.98 \times 10^{8 * * *}$ & $7.12 \times 10^{10^{* * *}}$ & $5.34 \times 10^{12^{* * *}}$ & 5000 \\
\hline
\end{tabular}

Least squares means; ns, *, ** non-significant or significant at $\mathrm{P}<0.05$ or $\mathrm{P}<0.01$ or $\mathrm{P}<0.001$ level of ANOVA, respectively. 
$\left.\mathrm{mg} \mathrm{L}^{-1}\right)$ and $\mathrm{SO}_{4}^{2-}\left(575.90 \mathrm{mg} \mathrm{L}^{-1}\right)$ present in the sugar mill effluent. The higher number of SPC $\left(9.23 \times 10^{14} \mathrm{SPC} \mathrm{ml}^{-1}\right)$ and MPN $\left(5.34 \times 10^{12} \mathrm{MPN} 100 \mathrm{ml}^{-1}\right)$ in the sugar mill effluent are likely due to the more TDS (1520 mg L-1), BOD (960.88 $\left.\mathrm{mg} \mathrm{L}^{-1}\right)$, COD (1670.20 $\left.\mathrm{mg} \mathrm{L}^{-1}\right)$ and TKN (172.60 $\left.\mathrm{mg} \mathrm{L}^{-1}\right)$ in the sugar mill effluent. The higher number of MPN is might be associated with the domestic sewage received from the staff quarters and offices located in the premises of the sugar mill. Kumar and Chopra ${ }^{[48]}$ reported that the more numbers of SPC $\left(7.34 \times 10^{18} \mathrm{SPC} \mathrm{ml}^{-1}\right)$ and MPN $\left(5.85 \times 10^{16} \mathrm{MPN} 100 \mathrm{ml}^{-1}\right)$ in the sugar mill effluent are due to the presence of more dissolved solids and organic matter in the effluent. Moreover, the higher contents of TDS and TKN in the sugar mill effluent support the more contents of $\mathrm{Cd}(7.28 \mathrm{mg}$ $\left.\mathrm{L}^{-1}\right), \mathrm{Cr}\left(1.42 \mathrm{mg} \mathrm{L}^{-1}\right), \mathrm{Cu}\left(8.05 \mathrm{mg} \mathrm{L}^{-1}\right), \mathrm{Fe}\left(19.45 \mathrm{mg} \mathrm{L}^{-1}\right), \mathrm{Mn}$ (6.42 $\left.\mathrm{mg} \mathrm{L}^{-1}\right)$ and $\mathrm{Zn}\left(10.34 \mathrm{mg} \mathrm{L}^{-1}\right)$ in the sugar mill effluent. Vijayaragavan et al. ${ }^{[38]}$ also reported the higher contents of $\mathrm{Cd}$ (10.50 $\left.\mathrm{mg} \mathrm{L}^{-1}\right), \mathrm{Cr}\left(3.80 \mathrm{mg} \mathrm{L}^{-1}\right), \mathrm{Cu}\left(14.75 \mathrm{mg} \mathrm{L}^{-1}\right), \mathrm{Fe}(22.85$ $\left.\mathrm{mg} \mathrm{L}^{-1}\right), \mathrm{Mn}\left(6.00 \mathrm{mg} \mathrm{L}^{-1}\right)$ and $\mathrm{Zn}\left(16.40 \mathrm{mg} \mathrm{L}^{-1}\right)$ in the sugar mill effluent.

\section{Effects of sugar mill effluent on soil characteristics}

Tables 2-4 show the ANOVA data on physico-chemical characteristics of the soil after treatment with different concentrations of the sugar mill effluent. At harvest of $S$. melongena (120 days after plantation), the ANOVA data indicated that season, concentrations of the sugar mill effluent and their interaction showed insignificant change $(\mathrm{P}>0.05)$ in the soil texture (loamy sand; $40 \%$ sand: $40 \%$ silt: $20 \%$ clay), BD and WHC (Table 2 ). The season, concentrations of the sugar mill effluent and their interaction with season showed significant $(\mathrm{P}<0.05 / \mathrm{P}<0.01)$ effect on $\mathrm{OC}, \mathrm{Na}^{+}, \mathrm{K}^{+}, \mathrm{Ca}^{2+}, \mathrm{Mg}^{2+}, \mathrm{TKN}, \mathrm{PO}_{4}{ }^{3-}, \mathrm{SO}_{4}{ }^{2-}, \mathrm{Cd}, \mathrm{Cr}, \mathrm{Cu}$, $\mathrm{Fe}, \mathrm{Mn}$ and $\mathrm{Zn}$ in both seasons (Tables 2-4). The season did not show significant $(\mathrm{P}>0.05)$ change in the $\mathrm{EC}$ and $\mathrm{pH}$ of the soil but the concentrations of the sugar mill effluent and their interaction with season showed significant $(\mathrm{P}<0.05)$ change in the $\mathrm{EC}$ and $\mathrm{pH}$ of the soil (Table 2).
Table 2: ANOVA for effect of sugar mill effluent (SME) on soil characteristics.

\begin{tabular}{|l|c|c|c|c|c|c|c|}
\hline Source & & WHC & BD & EC & pH & OC & TKN \\
\hline Season (S) & $\mathrm{ns}$ & $\mathrm{ns}$ & $\mathrm{ns}$ & $\mathrm{ns}$ & $*$ & $*$ & \\
\hline SME concentration $(\mathrm{C})$ & $\mathrm{ns}$ & $\mathrm{ns}$ & $*$ & $*$ & $* *$ & $* *$ & \\
\hline Interaction & $\mathrm{ns}$ & $\mathrm{ns}$ & $*$ & $*$ & $* *$ & $* *$ & \\
$\mathrm{~S} \times \mathrm{C}$ & & & & & & & \\
\hline
\end{tabular}

SME- sugar mill effluent; ns, *,** non-significant or significant at $\mathrm{P}<0.05$ or $\mathrm{P}<0.01$ level of ANOVA, respectively.

Table 3: ANOVA for effect of sugar mill effluent on cations in soil.

\begin{tabular}{|l|c|c|c|c|c|c|}
\hline Source & $\mathrm{Na}^{+}$ & $\mathrm{K}^{+}$ & $\mathrm{Ca}^{2+}$ & $\mathrm{Mg}^{2+}$ & $\mathrm{PO}_{4}^{3-}$ & $\mathrm{SO}_{4}^{2-}$ \\
\hline Season (S) & $*$ & $*$ & $*$ & $*$ & $*$ & $*$ \\
\hline SME concentration $(\mathrm{C})$ & $*$ & $*$ & $* *$ & $*$ & $* *$ & $*$ \\
\hline$\underline{\text { Interaction }} \times \mathrm{C}$ & $*$ & $* *$ & $* *$ & $* *$ & $* *$ & $*$ \\
\hline
\end{tabular}

SME- sugar mill effluent; *, ** significant at $\mathrm{P}<0.05$ or $\mathrm{P}<0.01$ level of ANOVA, respectively.

Table 4: ANOVA for effect of sugar mill effluent on metals in soil.

\begin{tabular}{|l|c|c|c|c|c|c|c|}
\hline Source & & $\mathrm{Cd}$ & $\mathrm{Cr}$ & $\mathrm{Cu}$ & $\mathrm{Fe}$ & $\mathrm{Mn}$ & $\mathrm{Zn}$ \\
\hline Season (S) & $*$ & $*$ & $*$ & $*$ & $\mathrm{~ns}$ & $*$ & \\
\hline SME concentration $(\mathrm{C})$ & $* *$ & $* *$ & $* *$ & $* *$ & $*$ & $* *$ & \\
\hline Interaction & $* *$ & $* *$ & $* *$ & $* *$ & $* *$ & $* *$ & \\
$\mathrm{~S} \times \mathrm{C}$ & & & & & & & \\
\hline
\end{tabular}

SME- sugar mill effluent; *, ** significant at $\mathrm{P}<0.05$ or $\mathrm{P}<0.01$ level of ANOVA, respectively.

Table 5: Effects of sugar mill effluent concentration and season interaction on physico-chemical characteristics of soil used in the cultivation of $S$. melongena in both seasons.

\begin{tabular}{|c|c|c|c|c|c|c|c|c|}
\hline \multicolumn{2}{|c|}{ Season $\times \%$ SME } & $\mathrm{EC}\left(\mathrm{dS} \mathrm{m}^{-1}\right)$ & $\mathrm{pH}$ & $\mathrm{OC}\left(\mathrm{mg} \mathrm{kg}^{-1}\right)$ & $\mathrm{Na}^{+}\left(\mathrm{mg} \mathrm{kg}^{-1}\right)$ & $\mathrm{K}^{+}\left(\mathrm{mg} \mathrm{kg}^{-1}\right)$ & $\mathrm{Ca}^{2+}\left(\mathrm{mg} \mathrm{kg}^{-1}\right)$ & $\mathrm{Mg}^{2+}\left(\mathrm{mg} \mathrm{kg}^{-1}\right)$ \\
\hline \multirow[t]{6}{*}{ Rainy } & 0 & 1.18 & 7.52 & 0.45 & 22.48 & 150.36 & 45.98 & 38.60 \\
\hline & 20 & $1.68 \mathrm{~ns}$ & $7.64 \mathrm{~ns}$ & $2.69^{*}$ & $28.94 *$ & $166.74 \mathrm{~ns}$ & $55.67 *$ & $48.64 *$ \\
\hline & 40 & $3.76^{*}$ & $7.84 \mathrm{~ns}$ & $5.78 * *$ & $54.77 *$ & $195.68^{* *}$ & $75.94 * *$ & $65.72 * *$ \\
\hline & 60 & $5.56^{*}$ & $7.98^{*}$ & $7.94 * *$ & $68.95 *$ & $244.80 * *$ & $86.94 * *$ & $86.30 * *$ \\
\hline & 80 & $7.66^{*}$ & $8.12 *$ & $9.67 * *$ & $82.48 * *$ & $275.94 *$ & $136.85^{* *}$ & 102.14* \\
\hline & 100 & $9.86^{* *}$ & $8.64 *$ & $12.94 * *$ & $90.26^{* *}$ & $298.64 *$ & $186.95 * *$ & $125.94 *$ \\
\hline \multirow[t]{6}{*}{ Summer } & 0 & 1.19 & 7.54 & 0.48 & 23.48 & 155.36 & 46.80 & 40.36 \\
\hline & 20 & $1.86 \mathrm{~ns}$ & $7.75 \mathrm{~ns}$ & $2.95^{*}$ & $30.25^{*}$ & $175.40 \mathrm{~ns}$ & $62.40^{*}$ & $58.64 *$ \\
\hline & 40 & $4.52 *$ & $7.94 \mathrm{~ns}$ & $6.15^{* *}$ & $56.84 *$ & $182.69^{*}$ & $86.37 * *$ & $75.94 * *$ \\
\hline & 60 & $6.32 *$ & $8.15^{*}$ & $8.56^{* *}$ & $78.48 *$ & $230.84 *$ & $115.61 * *$ & $98.45 * *$ \\
\hline & 80 & $9.47 *$ & $8.38 *$ & $10.36^{* * *}$ & $85.49 * *$ & $264.84 * *$ & $152.69 * * *$ & $124.60 * * *$ \\
\hline & 100 & $11.20 * *$ & $8.84^{*}$ & $14.58 * * *$ & $95.48 * *$ & $305.90 * *$ & $205.64 * * *$ & $138.95^{* * *}$ \\
\hline
\end{tabular}

Least squares means analysis; SME- sugar mill effluent; ns, * ** non-significant or significant at $\mathrm{P}<0.05$ or $\mathrm{P}<0.01$ or $\mathrm{P}<0.001$ level of ANOVA, respectively. 
Table 5: Effects of sugar mill effluent concentration and season interaction on physico-chemical characteristics of soil used in the cultivation of S. melongena in both seasons.

\begin{tabular}{|c|c|c|c|c|c|c|c|c|c|c|}
\hline \multicolumn{2}{|c|}{ Season $\times \%$ SME } & $\begin{array}{c}\mathrm{TKN} \\
\left(\mathrm{mg} \mathrm{kg}^{-1}\right)\end{array}$ & $\begin{array}{c}\mathrm{PO}_{4}^{3-} \\
\left(\mathrm{mg} \mathrm{kg}^{-1}\right)\end{array}$ & $\begin{array}{c}\mathrm{SO}_{4}^{2-} \\
\left(\mathrm{mg} \mathrm{kg}^{-1}\right)\end{array}$ & $\begin{array}{c}\mathrm{Cd} \\
\left(\mathrm{mg} \mathrm{kg}^{-1}\right)\end{array}$ & $\begin{array}{c}\mathrm{Cr} \\
\left(\mathrm{mg} \mathrm{kg}^{-1}\right)\end{array}$ & $\begin{array}{c}\mathrm{Cu} \\
\left(\mathrm{mg} \mathrm{kg}^{-1}\right)\end{array}$ & $\begin{array}{c}\mathrm{Fe} \\
\left(\mathrm{mg} \mathrm{kg}^{-1}\right)\end{array}$ & $\begin{array}{c}\mathrm{Mn} \\
\left(\mathrm{mg} \mathrm{kg}^{-1}\right)\end{array}$ & $\begin{array}{c}\mathrm{Zn} \\
\left(\mathrm{mg} \mathrm{kg}^{-1}\right)\end{array}$ \\
\hline \multirow{6}{*}{ Rainy } & 0 & 32.60 & 24.50 & 60.20 & 0.42 & 0.32 & 1.18 & 1.69 & 0.52 & 0.63 \\
\hline & 20 & $74.85^{* *}$ & $38.60^{*}$ & $86.94 *$ & $1.05^{*}$ & $0.68^{*}$ & $3.69 *$ & $5.58^{*}$ & $2.15^{*}$ & $1.95^{*}$ \\
\hline & 40 & $162.40^{* *}$ & $58.90^{*}$ & $142.63 * *$ & $2.75^{*}$ & $1.06^{* *}$ & $5.94 *$ & $7.84 * *$ & $4.60 *$ & $3.94 *$ \\
\hline & 60 & $280.20 * *$ & $84.75^{* *}$ & $170.64 * *$ & $4.64 * *$ & $1.44 * *$ & $8.67 * *$ & $9.68 * *$ & $6.91 *$ & $7.09 * *$ \\
\hline & 80 & $340.70^{* *}$ & $115.64 * *$ & $206.94 * *$ & $5.96 * *$ & $2.64 * *$ & $10.94 * * *$ & $12.94 * *$ & $7.94 * *$ & $10.95 * * *$ \\
\hline & 100 & $428.96^{*}$ & $137.83 * *$ & $234.80 * *$ & $7.33 * *$ & $2.96^{* *}$ & $12.88 * * *$ & $16.94 * *$ & $10.62 * * *$ & $13.94 * * *$ \\
\hline \multirow{6}{*}{ Summer } & 0 & 34.26 & 25.64 & 62.32 & 0.43 & 0.32 & 1.19 & 1.72 & 0.53 & 0.64 \\
\hline & 20 & $82.94 * *$ & $46.50^{*}$ & $92.67 *$ & $1.14^{*}$ & $1.12 *$ & $3.95^{*}$ & $6.88^{*}$ & $2.85^{*}$ & $2.26^{*}$ \\
\hline & 40 & $195.75^{* *}$ & $70.94 *$ & $156.39 * *$ & $2.96^{*}$ & $1.65 * *$ & $6.42 *$ & $8.67 * *$ & $5.38 *$ & $5.64 *$ \\
\hline & 60 & $296.80^{* *}$ & $102.60 * *$ & $185.94 * *$ & $5.12 * *$ & $1.95^{* *}$ & $9.68 * *$ & $10.64 * *$ & $7.61 * *$ & $9.67 * *$ \\
\hline & 80 & $368.88^{* * *}$ & $130.48 * * *$ & $226.55^{* * *}$ & $6.44 * * *$ & $2.75^{* * *}$ & $12.94 * * *$ & $14.69 * * *$ & $10.26 * * *$ & $13.54 * *$ \\
\hline & 100 & $445.80 * * *$ & $154.66^{* * *}$ & $243.80 * * *$ & $8.15 * * *$ & $3.15^{* * *}$ & $14.20 * *$ & $18.85^{* * *}$ & $12.39 * *$ & $15.32 * * *$ \\
\hline
\end{tabular}

Least squares means analysis; SME- sugar mill effluent; ns, * ** non-significant or significant at $\mathrm{P}<0.05$ or $\mathrm{P}<0.01$ or $\mathrm{P}<0.001$ level of ANOVA, respectively.

During the present study, irrigation with $100 \%$ concentration of the sugar mill effluent showed the most increase in the $\mathrm{EC}, \mathrm{OC}, \mathrm{Na}^{+}, \mathrm{K}^{+}, \mathrm{Ca}^{2+}, \mathrm{Mg}^{2+}, \mathrm{TKN}, \mathrm{PO}_{4}^{3-}, \mathrm{SO}_{4}^{2-}, \mathrm{Cd}, \mathrm{Cr}, \mathrm{Cu}$, $\mathrm{Fe}, \mathrm{Mn}$ and $\mathrm{Zn}$ in both seasons (Table 5). The values of WHC and $\mathrm{BD}$ of the sugar mill effluent irrigated soil were insignificantly changed with different concentrations of the sugar mill effluent in both the seasons. The WHC and BD of the soil were reduced from their control values $44.60 \%$ and $1.42 \mathrm{gm} \mathrm{cm}^{-3}$ to $42.80,42.96 \%$ and $1.41 \mathrm{gm} \mathrm{cm}^{-3}$, respectively due to irrigation with $100 \%$ concentration of the sugar mill effluent. The WHC is related to the number and size distribution of soil pores, soil moisture content, textural class, and structure, salt content and organic matter. The BD of soil changes with the application of organic manure to soil that substantially modifies, and lowers the soil bulk density. It is used for determining the amount of pore space and water storage capacity of the soil. The organic matter supplied through the sugar mill effluent can lower the BD and WHC as earlier reported by Maliwal et al. ${ }^{[30]}$. The findings of the present study are also in accordance to Kumar and Chopra ${ }^{[54]}$ who reported that the higher contents of OC in sewage effluent lowered the BD and WHC of the soil.

The results showed that 40 to $100 \%$ concentrations of the sugar mill effluent significantly $(\mathrm{P}<0.05 / \mathrm{P}<0.01 / \mathrm{P}<0.001)$ affected $\mathrm{EC}, \mathrm{OC}, \mathrm{Na}^{+}, \mathrm{K}^{+}, \mathrm{Ca}^{2+}, \mathrm{Mg}^{2+}, \mathrm{TKN}, \mathrm{PO}_{4}^{3-}, \mathrm{SO}_{4}^{2-}, \mathrm{Cd}$, $\mathrm{Cr}, \mathrm{Cu} \mathrm{Fe}, \mathrm{Mn}$ and $\mathrm{Zn}$ of the soil used for the cultivation of $S$. melongena in both seasons (Table 5). The $\mathrm{pH}$ (8.64 and 8.84) of the soil was found more alkaline with $100 \%$ treatment of the sugar mill effluent and it is likely due to the alkaline nature $(\mathrm{pH}$ 8.80 ) of the sugar mill effluent. The higher values of EC of the sugar mill effluent irrigated soil might be due to the presence of more cations and anions in the soil suspension. Moreover, the $\mathrm{EC}, \mathrm{OC}, \mathrm{Na}^{+}, \mathrm{K}^{+}, \mathrm{Ca}^{2+}, \mathrm{Mg}^{2+}, \mathrm{TKN}, \mathrm{PO}_{4}^{3-}, \mathrm{SO}_{4}^{2-}, \mathrm{Cd}, \mathrm{Cr}, \mathrm{Cu}, \mathrm{Fe}$, $\mathrm{Mn}$ and $\mathrm{Zn}$ of the soil were noted to be positively correlated with different concentrations of the sugar mill effluent in both seasons (Table 6). Thus there was gradual build up of $\mathrm{EC}, \mathrm{OC}, \mathrm{Na}^{+}, \mathrm{K}^{+}$, $\mathrm{Ca}^{2+}, \mathrm{Mg}^{2+}, \mathrm{TKN}, \mathrm{PO}_{4}^{3-}, \mathrm{SO}_{4}^{2-}, \mathrm{Cd}, \mathrm{Cr}, \mathrm{Cu}, \mathrm{Fe}, \mathrm{Mn}$ and $\mathrm{Zn}$ of the soil due to the concentrations of the sugar mill effluent.
Table 6: Coefficient of correlation (r) between sugar mill effluent and soil characteristics

\begin{tabular}{|c|c|c|}
\hline Sugar mill effluent /soil characteristics & Season & $\mathrm{r}$ - value \\
\hline \multirow{2}{*}{ Sugar mill effluent versus soil EC } & Rainy & +0.94 \\
\hline & Summer & +0.95 \\
\hline \multirow{2}{*}{ Sugar mill effluent versus soil $\mathrm{pH}$} & Rainy & -0.90 \\
\hline & Summer & -0.92 \\
\hline \multirow{2}{*}{ Sugar mill effluent versus soil OC } & Rainy & +0.97 \\
\hline & Summer & +0.98 \\
\hline \multirow{2}{*}{ Sugar mill effluent versus soil $\mathrm{Na}^{+}$} & Rainy & +0.92 \\
\hline & Summer & +0.94 \\
\hline \multirow{2}{*}{ Sugar mill effluent versus soil $\mathrm{K}^{+}$} & Rainy & +0.88 \\
\hline & Summer & +0.90 \\
\hline \multirow{2}{*}{ Sugar mill effluent versus soil $\mathrm{Ca}^{2+}$} & Rainy & +0.94 \\
\hline & Summer & +0.96 \\
\hline \multirow{2}{*}{ Sugar mill effluent versus soil $\mathrm{Mg}^{2+}$} & Rainy & +0.82 \\
\hline & Summer & +0.84 \\
\hline \multirow{2}{*}{ Sugar mill effluent versus soil TKN } & Rainy & +0.96 \\
\hline & Summer & +0.98 \\
\hline \multirow{2}{*}{ Sugar mill effluent versus soil $\mathrm{PO}_{4}^{3-}$} & Rainy & +0.95 \\
\hline & Summer & +0.96 \\
\hline \multirow{2}{*}{ Sugar mill effluent versus soil $\mathrm{SO}_{4}^{2-}$} & Rainy & +0.92 \\
\hline & Summer & +0.94 \\
\hline \multirow{2}{*}{ Sugar mill effluent versus soil Fe } & Rainy & +0.95 \\
\hline & Summer & +0.96 \\
\hline \multirow{2}{*}{ Sugar mill effluent versus soil Cd } & Rainy & +0.90 \\
\hline & Summer & +0.92 \\
\hline \multirow{2}{*}{ Sugar mill effluent versus soil $\mathrm{Cr}$} & Rainy & +0.86 \\
\hline & Summer & +0.88 \\
\hline \multirow{2}{*}{ Sugar mill effluent versus soil $\mathrm{Cu}$} & Rainy & +0.96 \\
\hline & Summer & +0.98 \\
\hline \multirow{2}{*}{ Sugar mill effluent versus soil Mn } & Rainy & +0.94 \\
\hline & Summer & +0.95 \\
\hline \multirow{2}{*}{ Sugar mill effluent versus soil $\mathrm{Zn}$} & Rainy & +0.96 \\
\hline & Summer & +0.98 \\
\hline
\end{tabular}


Rakkiyappan et al. ${ }^{[5]}$ reported that sugar mill effluent amendments increased $\mathrm{EC}, \mathrm{pH}$, total organic carbon (TOC), total Kjeldahl nitrogen (TKN), and available phosphorus, exchangeable $\mathrm{Na}, \mathrm{K}, \mathrm{Ca}$ and $\mathrm{Mg}$ in soil. The soil $\mathrm{pH}$ is an important parameter as many nutrients are available to plants only within a particular $\mathrm{pH}$ range. A pH range of 6.0 to 9.4 enhances nutrient availability for plants, and a pH below 6.0 and above 8.8 inhibits the availability of nutrients for plants ${ }^{[6--58]}$. In the present study $\mathrm{pH}$ of the soil was ranged $8.58-8.80$ with $100 \%$ treatment of the sugar mill effluent which makes the various soil nutrients available to the plants.

The contents of TKN and OC in the soil irrigated with sugar mill effluent were recorded higher than the control soil. The more organic carbon in sugar mill effluent irrigated soil might be due to the high organic nature of the sugar mill effluent. Kumar and Chopra ${ }^{[46]}$ found higher organic content in the soil irrigated with sugar mill effluent. The higher values of $\mathrm{Na}^{+}$, $\mathrm{K}^{+}, \mathrm{Ca}^{2+}, \mathrm{Mg}^{2+}, \mathrm{PO}_{4}^{3-}$ and $\mathrm{SO}_{4}^{2-}$ in the soil treated with sugar mill effluent were likely due to the more contents of $\mathrm{Na}^{+}, \mathrm{K}^{+}$, $\mathrm{Ca}^{2+}, \mathrm{Mg}^{2+}, \mathrm{PO}_{4}^{3-}$ and $\mathrm{SO}_{4}^{2-}$ in the sugar mill effluent. The varied accumulation of the $\mathrm{Na}\left(3 s^{1}\right), \mathrm{K}\left(4 s^{1}\right), \mathrm{Ca}\left(4 s^{2}\right), \mathrm{Mg}\left(3 s^{2}\right), \mathrm{P}$ $\left(3 p^{3}\right) ; \mathrm{S}\left(3 p^{4}\right), \mathrm{Fe}\left(3 d^{6}\right), \mathrm{Cd}\left(4 d^{10}\right), \mathrm{Cr}\left(3 d^{5}\right), \mathrm{Cu}\left(3 d^{10}\right), \mathrm{Mn}\left(3 d^{5}\right)$ and $\mathrm{Zn}\left(3 d^{10}\right)$ in the soil after effluent irrigation is likely due to the electrons present in their $s, p$ and $d$ orbitals which determine their stability, reactivity, oxidation and reduction in the aqueous environment.

The contents of heavy metals, $\mathrm{Cd}, \mathrm{Cr}, \mathrm{Cu}, \mathrm{Fe}, \mathrm{Mn}$ and $\mathrm{Zn}$ in the soil were increased with the increase in the concentrations of the sugar mill effluent. The contamination factor (Cf) of the heavy metals indicated that $\mathrm{Zn}(22.13$ and 23.94) was highest while $\mathrm{Cr}$ (9.25 and 9.84) was lower in both seasons after treatment with $100 \%$ sugar mill effluent. The $\mathrm{Cf}$ of heavy metals were in the order of $\mathrm{Zn}>\mathrm{Mn}>\mathrm{Cd}>\mathrm{Cu}>\mathrm{Fe}>\mathrm{Cr}$ after irrigation with sugar mill effluent in both seasons (Figure 1). Although, the contents of heavy metals except $\mathrm{Cd}\left(6.0 \mathrm{mg} \mathrm{kg}^{-1}\right)$ were found below the maximum levels permitted for the $\mathrm{Cr}\left(10.0 \mathrm{mg} \mathrm{kg}^{-1}\right), \mathrm{Cu}(270$ $\left.\mathrm{mg} \mathrm{kg}^{-1}\right)$ and $\mathrm{Zn}\left(600 \mathrm{mg} \mathrm{kg}^{-1}\right)$ for the soils in India ${ }^{[59]}$. However, there was a gradual build up of these metals in the sugar mill effluent irrigated soil. Thus, sugar mill effluent irrigation increased the nutrients and metals in the soil used for the cultivation of $S$. melongena.

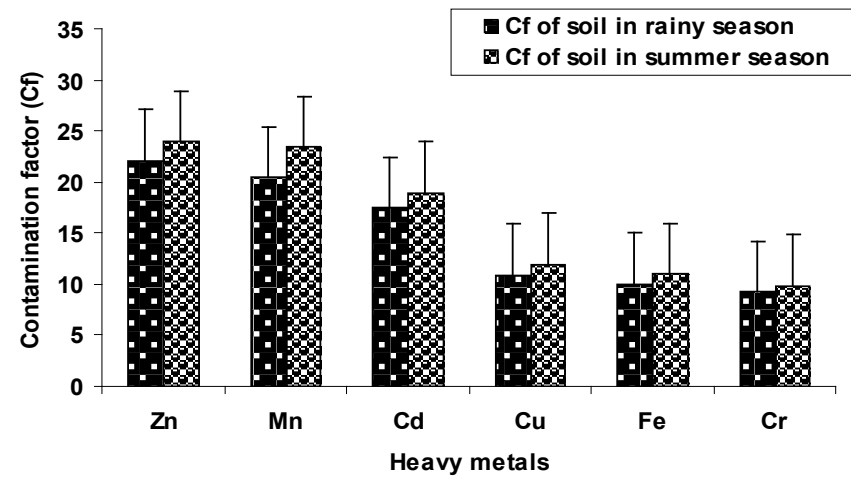

Figure 1: Contamination factor of heavy metals in soil after irrigation with sugar mill effluent. Error bars are standard error of the mean.

\section{Effect of sugar mill effluent on seed germination of $S$. mel-} ongena

The percent seed germination of S. melongena after irrigation with sugar mill effluent is shown in figure 2. During the present study, most seed germination (86.00 and $88.00 \%$ ) of $S$. melongena was observed with $60 \%$ concentration of the sugar mill effluent, while the least seed germination $(80.00 \%$ and $82 \%$ ) was noted with $100 \%$ concentration of the sugar mill effluent (Figure 2). The seed germination of $S$. melongena was noted to be negatively correlated $(r=-0.56$ and -0.58$)$ with different concentrations of the sugar mill effluent in both the seasons. At germination stage, ANOVA indicated that seasons showed insignificant $(\mathrm{P}>0.05)$ effect on the seed germination of $S$. melonge$n a$ and relative toxicity (RT) against the seed germination while sugar mill effluent concentrations and their interaction with seasons showed significant $(\mathrm{P}<0.05)$ effect on the seed germination of $S$. melongena and RT of the sugar mill effluent against the seed germination (Table 7). The findings are in agreement with Chopra et al. ${ }^{[53]}$ who reported that the germination of okra (Abelmoschus esculentus L.) was decreased with the increase in the concentration of distillery effluent. In the present study, the higher concentrations $(60 \%$ to $100 \%)$ of the sugar mill effluent did not support the seed germination of $S$. melongena. Kumar and Chopra ${ }^{[9]}$ also reported that the germination of French bean (Phaseolus vulgaris L.) was decreased when the concentration of effluent increased. The higher concentrations (i.e. $80 \%$ and $100 \%$ ) of the sugar mill effluent lowered the seed germination of S. melongena. It may be likely due to the presence of more contents of salts and heavy metals in the sugar mill effluent at higher concentrations of sugar mill effluent. The most RT (103.24\% and $104.86 \%$ ) of the sugar mill effluent against seed germination of $S$. melongena was recorded with $100 \%$ concentration of the sugar mill effluent (Figure 3). Moreover the RT was found to be significantly $(\mathrm{P}<0.05)$ and positively correlated $(\mathrm{r}=+0.64)$ with different concentrations of the sugar mill effluent.

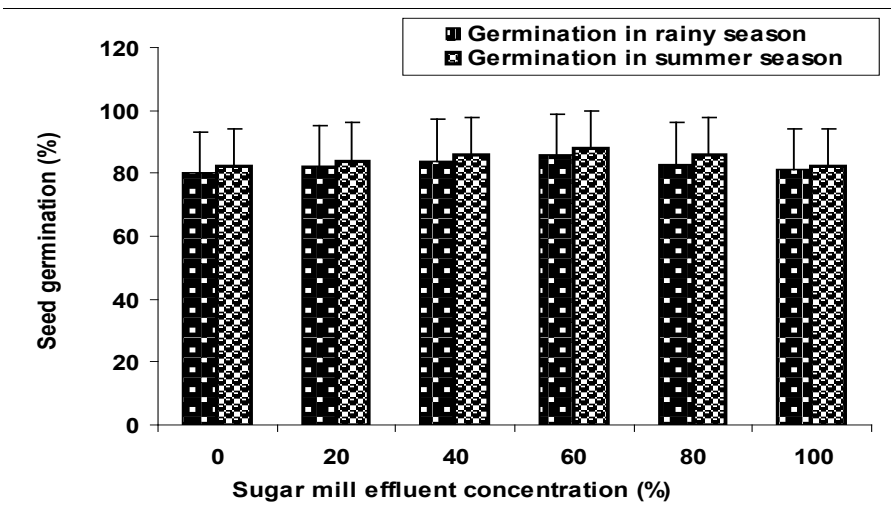

Figure 2: Seed germination of $S$. melongena after irrigation with sugar mill effluent. Error bars are standard error of the mean.

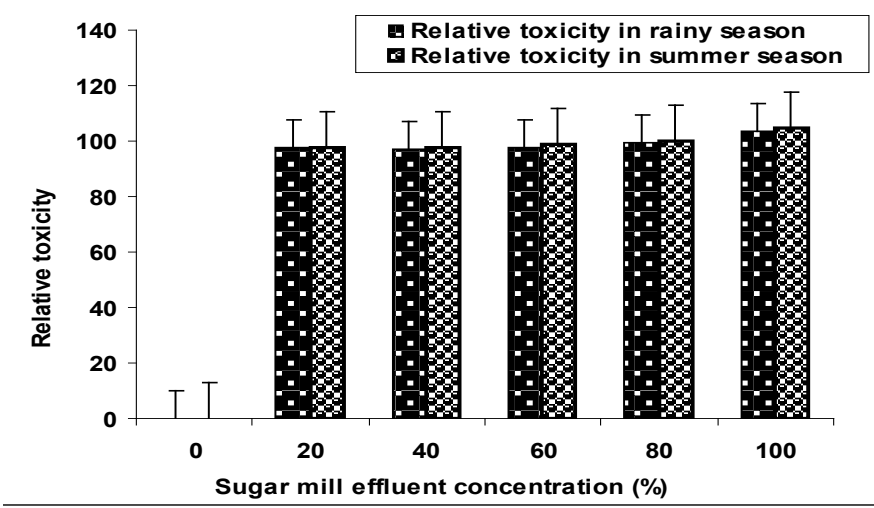

Figure 3: Relative toxicity of sugar mill effluent against seed 
Sugar Mill Effluent Irrigation \& Effects

Table 7: ANOVA for effects of sugar mill effluent on different parameters of S. melongena.

\begin{tabular}{|l|c|c|c|c|c|c|c|c|}
\hline Source & Seed germination & Relative toxicity & Plant height & Root length & $\begin{array}{c}\text { Chlorophyll } \\
\text { content }\end{array}$ & LAI & Dry weight & CY/plant \\
\hline Season $(\mathrm{S})$ & $\mathrm{ns}$ & $\mathrm{ns}$ & $\mathrm{ns}$ & $\mathrm{ns}$ & $\mathrm{ns}$ & $\mathrm{ns}$ & $\mathrm{ns}$ & $\mathrm{ns}$ \\
\hline SME concentration $(\mathrm{C})$ & $*$ & $*$ & $*$ & $\mathrm{~ns}$ & $*$ & $*$ & $\mathrm{~ns}$ & $*$ \\
\hline$\underline{\text { Interaction }}$ & $*$ & $*$ & $*$ & $\mathrm{~ns}$ & $*$ & $*$ & $\mathrm{~ns}$ & $*$ \\
\hline
\end{tabular}

SME- Sugar mill effluent; ns, *, non-significant or significant at $\mathrm{P}<0.05$ level of ANOVA, respectively.

germination of S. melongena. Error bars are standard error of the mean. Effect of sugar mill effluent on vegetative growth of S. melongena

Table 7 shows the ANOVA data for the effects of season, concentrations of the sugar mill effluent and their interaction on the attributes of the vegetative growth stage of $S$. melongena. The ANOVA indicated that concentrations of the sugar mill effluent and their interaction with season significantly $(\mathrm{P}<0.05)$ affected the plant height, chlorophyll content, and LAI of $S$. melongena in both the seasons. The season showed insignificant effect $(\mathrm{P}>0.05)$ on the vegetative growth attributes of $S$. melongena. Moreover season, concentrations of the sugar mill effluent and their interaction did not show significant effect on the root length of $S$. melongena.

In the present study, at vegetative growth at 75 days the maximum plant height (134.67 and $148.90 \mathrm{~cm})$, root length (19.14 and $21.45 \mathrm{~cm}$ ), dry weight (1264.50 and $1295.80 \mathrm{~g}$ ), chlorophyll content (3.84 and $4.15 \mathrm{mg}$./g.f.wt) and LAI/plant (3.45 and 3.64) of $S$. melongena were observed with $60 \%$ concentration of the sugar mill effluent in both the seasons. The minimum plant height $(107.55$ and $112.76 \mathrm{~cm})$, root length $(13.87$ and $14.23 \mathrm{~cm})$, dry weight $(880.24$ and $896.90 \mathrm{~g})$, chlorophyll content (3.12 and 3.18 mg./g.f.wt) and LAI/plant (3.24 and 3.30) of $S$. melongena were observed with control, while the moderate plant height $(120.40$ and $128.70 \mathrm{~cm})$, root length $(15.65$ and $16.12 \mathrm{~cm}$ ), dry weight (955.34 and $974.55 \mathrm{~g}$ ), chlorophyll content (3.35 and $3.40 \mathrm{mg} . / \mathrm{g}$.f.wt) and LAI/plant (3.30 and 3.37) of S. melongena were noted with $100 \%$ concentration of the sugar mill effluent in both seasons.

During the present study, plant height, root length, dry weight, chlorophyll content and LAI/plant of S. melongena were noted to be positively correlated with different concentrations of the sugar mill effluent in both the seasons (Table 8). Prabhu et al. ${ }^{[34]}$ reported that the growth of $S$. melongena was decreased when the concentration of wastewater effluent increased. Likewise, Kumar and Chopra ${ }^{[9]}$ reported that the maximum vegetative growth attributes like plant height, root length, dry weight, chlorophyll content and leaf area index of French bean (Phaseolus vulgaris L.) was noted with $60 \%$ concentration of the sugar mill effluent. Furthermore, the growth of P. vulgaris was decreased with the increase in sugar mill effluent concentration from $60 \%$ to $100 \%$. The findings were also supported by Fukuoka et al. ${ }^{[35]}$ who reported that the growth of eggplant was decreased due to the application of more concentration of waste effluent.
Table 8: Coefficient of correlation (r) between sugar mill effluent and S. melongena.

\begin{tabular}{|l|l|c|}
\hline Sugar mill effluent / S. melongena & Season & $\mathrm{r}$ - value \\
\hline \multirow{2}{*}{ Sugar mill effluent versus plant height } & Rainy & +0.45 \\
\cline { 2 - 3 } & Summer & +0.48 \\
\hline \multirow{2}{*}{ Sugar mill effluent versus root length } & Rainy & +0.27 \\
\cline { 2 - 3 } & Summer & +0.28 \\
\hline \multirow{2}{*}{ Sugar mill effluent versus dry weight } & Rainy & +0.36 \\
\cline { 2 - 3 } & Summer & +0.39 \\
\hline \multirow{2}{*}{ Sugar mill effluent versus chlorophyll content } & Rainy & +0.54 \\
\cline { 2 - 3 } & Summer & +0.56 \\
\hline \multirow{2}{*}{ Sugar mill effluent versus LAI } & Rainy & +0.52 \\
\cline { 2 - 3 } & Summer & +0.54 \\
\hline \multirow{2}{*}{ Sugar mill effluent versus crop yield/plant } & Rainy & +0.42 \\
\cline { 2 - 3 } & Summer & -0.44 \\
\hline \multirow{2}{*}{ Sugar mill effluent versus Cd } & Rainy & +0.90 \\
\cline { 2 - 3 } & Summer & +0.92 \\
\hline \multirow{2}{*}{ Sugar mill effluent versus Cr } & Rainy & +0.74 \\
\cline { 2 - 3 } & Summer & +0.76 \\
\hline \multirow{2}{*}{ Sugar mill effluent versus Cu } & Rainy & +0.96 \\
\cline { 2 - 3 } & Summer & +0.98 \\
\hline \multirow{2}{*}{ Sugar mill effluent versus Fe } & Rainy & +0.94 \\
\cline { 2 - 3 } & Summer & +0.96 \\
\hline \multirow{2}{*}{ Sugar mill effluent versus Mn } & Rainy & +0.92 \\
\cline { 2 - 3 } & Summer & +0.94 \\
\hline \multirow{2}{*}{ Sugar mill effluent versus crude proteins } & Rainy & +0.96 \\
\cline { 2 - 3 } & Summer & +0.98 \\
\hline & Rainy & +0.52 \\
\hline & Summer & +0.54 \\
\hline & Summer & +0.58 \\
\cline { 2 - 3 } & Rainy & +0.64 \\
\cline { 2 - 3 } & Summer & +0.68 \\
\hline \multirow{2}{*}{ Suing } & +0.60 \\
\hline
\end{tabular}

The results showed that the vegetative growth of $S$. melongena was decreased at higher (i.e. $80 \%$ to $100 \%$ ) concentrations of the sugar mill effluent. It might be due to the presence of more contents of the heavy metals in the higher concentrations of sugar mill effluent, which lowered the plant height, root length, dry weight, chlorophyll content and LAI/plant of S. melongena. Vegetative growth is concerned with the development of new 
shoots, leaves and leaf area ${ }^{[41]}$. The maximum plant height, root length, dry weight and LAI/plant of $S$. melongena were noted with $60 \%$ concentration of the sugar mill effluent, and it may be likely due to the maximum uptake of nitrogen $(\mathrm{N})$, phosphorus (P) and potassium (K) by $S$. melongena plants. The improvement of vegetative growth may be attributed to the role of $\mathrm{K}$ in the nutrient and sugar translocation in the plants and turgor pressure in the plant cells. It is also involved in the cell enlargement and in triggering young tissue or mersitematic growth ${ }^{[31,33]}$. The chlorophyll content was found higher due to the use of $60 \%$ concentration of the sugar mill effluent in both seasons, and is likely due to $\mathrm{Fe}, \mathrm{Mg}$ and $\mathrm{Mn}$ contents in the sugar mill effluent, which are associated with chlorophyll synthesis ${ }^{[34,54]}$. Thus, $60 \%$ concentration of the sugar mill effluent contains optimum contents of nutrients required for the maximum vegetative growth of $S$. melongena.

\section{Effect of sugar mill effluent on maturity of $\boldsymbol{S}$. melongena}

The ANOVA data indicated that the crop yield/plant of $S$. melongena were not affected by seasons, sugar mill effluent concentrations and their interaction (Table 7). Furthermore, the crop yield/plant of $S$. melongena was found to be positively correlated with all concentrations of the sugar mill effluent in both the seasons (Table 8). At maturity stage (120 days after sowing), the maximum yield/plant (1465.80 and $1525.65 \mathrm{~g})$ at I harvest, (1848.90 and $1886.60 \mathrm{~g})$ at II harvest and (1290.55 and $1366.77 \mathrm{~g}$ ) at III harvest of $S$. melongena were recorded with $60 \%$ concentration of the sugar mill effluent in both the seasons. The least crop yield/plant (1018.87 and $1058.43 \mathrm{~g})$ at I harvest, (1135.66 and $1189.80 \mathrm{~g}$ ) at II harvest and (1098.50 and 1108.90 $\mathrm{g}$ ) at III harvest of $S$. melongena were recorded with the control while moderate crop yield/plant (1230.10 and $1298.20 \mathrm{~g})$ at I harvest, (1566.54 and $1650.12 \mathrm{~g}$ ) at II harvest and (1168.30 g and $1257.42 \mathrm{~g}$ ) of $S$. melongena at III harvest were recorded with $100 \%$ treatment of the sugar mill effluent in both the seasons. At maturity stage the $60 \%$ concentration of the sugar mill effluent favored crop yield of $S$. melongena. This is likely due to the presence of optimal contents of $\mathrm{K}, \mathrm{Fe}, \mathrm{Mg}$ and $\mathrm{Mn}$ in the $60 \%$ concentration of the sugar mill effluent. Moreover, the higher concentrations (i.e. $80 \%$ to $100 \%$ ) of the sugar mill effluent lowered the crop yield of $S$. melongena. The reduction in the crop yield is likely due to the presence of higher contents of heavy metals, which reduced the uptake of nutrients by $S$. melongena plants.

The role of $\mathrm{K}, \mathrm{Fe}, \mathrm{Mg}$ and $\mathrm{Mn}$ at maturity is important and associated with synthesis of chlorophyll, and enhances the crop yield ${ }^{[48,51]}$. The $\mathrm{K}, \mathrm{Fe}, \mathrm{Mg}$ and $\mathrm{Mn}$ contents could enhance the yield of eggplants ( $S$. melongena) as reported by Fukuoka et al. ${ }^{[35]}$. Kumar et al. ${ }^{[39]}$ reported that the maximum crop yield of black gram (Vigna mungo L.) was noted with $40 \%$ concentration of effluent. Moreover, the crop yield of $V$. mungo was decreased with the increase in effluent concentration from $60 \%$ to $100 \%$.

\section{Effect on heavy metals and biochemical components in $S$. melongena}

Tables 9 and 10 show the ANOVA data for the effects of season, concentrations of the sugar mill effluent and their interaction on the contents of heavy metals and biochemical components in $S$. melongena. The ANOVA indicated that season, concentrations of the sugar mill effluent and their interaction significantly $(\mathrm{P}<0.05 / \mathrm{P}<0.01)$ affected the contents of heavy metals and biochemical components in S. melongena. The $20 \%$ to $100 \%$ concentrations of the sugar mill effluent showed significant $(\mathrm{P}<0.05 / \mathrm{P}<0.01)$ effect on $\mathrm{Cd}, \mathrm{Cr}, \mathrm{Cu}, \mathrm{Fe}, \mathrm{Mn}$ and $\mathrm{Zn}$, crude protein, dietary fiber, total carbohydrate and total sugar in $S$. melongena. The contents of $\mathrm{Cd}, \mathrm{Cr}, \mathrm{Cu}, \mathrm{Fe}, \mathrm{Mn}, \mathrm{Zn}$, crude protein, dietary fiber, total carbohydrate and total sugar were found to be positively correlated with all concentrations of the sugar mill effluent in both the seasons (Table 8). The most contents of $\mathrm{Cd}, \mathrm{Cr}, \mathrm{Cu}, \mathrm{Fe}, \mathrm{Mn}$ and $\mathrm{Zn}$ in $\mathrm{S}$. melongena were recorded with $100 \%$ treatment of the sugar mill effluent (Figures 4, 5). It might be due to the presence of higher contents of heavy metals in $100 \%$ treatment of the sugar mill effluent, which added more metals in the soil environment. The accumulation of $\mathrm{Cr}, \mathrm{Cu}, \mathrm{Fe}$, $\mathrm{Mn}$ and $\mathrm{Zn}$ except $\mathrm{Cd}$ in $\mathrm{S}$. melongena was noted below the permissible limit of FAO/WHO standards for $\mathrm{Cd}\left(0.20 \mathrm{mg} \mathrm{Kg}^{-1}\right)$, $\mathrm{Cr}\left(2.30 \mathrm{mg} \mathrm{Kg}^{-1}\right), \mathrm{Cu}\left(40.00 \mathrm{mg} \mathrm{Kg}^{-1}\right) \mathrm{Fe}\left(80.00 \mathrm{mg} \mathrm{Kg}^{-1}\right)$ and $\mathrm{Zn}\left(60.00 \mathrm{mg} \mathrm{Kg}^{-1}\right)^{[60]}$. The contamination factor $(\mathrm{Cf})$ of heavy metals was affected in both seasons. The $\mathrm{Cf}$ of the metals was noted in the order of $\mathrm{Fe}>\mathrm{Mn}>\mathrm{Cu}>\mathrm{Zn}>\mathrm{Cd}>\mathrm{Cr}$ in $\mathrm{S}$. melongena after application of sugar mill effluent (Figure 6). The highest contamination factor was noted for $\mathrm{Fe}$ (12.68 and 13.33), while the least was found for $\mathrm{Cr}$ (6.72 and 7.42) in S. melongena with $100 \%$ concentration of the sugar mill effluent in both the seasons. The diverse accumulation of these metals might be due to the number of electrons in the d-levels of the atom. Although, metals with completely filled d orbitals such as $\left(3 d^{10}\right.$ of $\mathrm{Cu}$ and $\mathrm{Zn}$ and $4 d^{10}$ of $\mathrm{Cd}$ ) may be least incorporated compared to $\left(3 d^{5}\right.$ of $\mathrm{Cr}$ and $\mathrm{Mn}$ ) into the $S$. melongena plants due to their lower reactivity and more stability imparted by the completely filled $\mathrm{d}$ orbitals. The lower reactivity and stability of these metals reduce the rate of various reactions such as absorption, ionic exchange, redox reactions, precipitation and dissolution through which plants take metals from the soils. However, the bioavailability of these metals might be increased due to the ionization in the aqueous phase in the soil which increases their reactivity and instability as earlier reported by Kumar et al. ${ }^{[39]}$. The results showed that the contents of these metals were more at $80 \%$ to $100 \%$ concentrations of the sugar mill effluent, and likely inhibited growth of $S$. melongena. The $60 \%$ treatment of the effluent favored vegetative growth and maturity of SS. melongena. This is likely due to optimal uptake of these metals by $S$. melongena plants, which supports various biochemical and physiological processes of the $S$. melongena plants. The results are in the conformity of Kumar and Chopra ${ }^{[25]}$ who reported the accumulation of metals in the order of $\mathrm{Fe}>\mathrm{Zn}>\mathrm{Cd}>\mathrm{Cu}>\mathrm{Cr}>\mathrm{Pb}$ in Vicia faba after irrigated with sugar mill effluent. Nunome et al. ${ }^{[33]}$ also reported the contamination of $\mathrm{Cd}, \mathrm{Cu}, \mathrm{Cr}, \mathrm{Zn}$ and $\mathrm{Pb}$ in soil and S. melongena after application of sugar mill effluent. During the present study, maximum contents of crude protein, dietary fiber, total carbohydrate and total sugar were noted with $60 \%$ concentration of the sugar mill effluent (Figures 7-10). The contents of crude protein, dietary fiber, total carbohydrate and total sugar were decreased from $80 \%$ to $100 \%$ concentrations of the sugar mill effluent. The findings are in agreement with Kumar and Chopra $^{[9,46]}$ who reported that the contents of total carbohydrate, crude protein and crude fiber in French bean (Phaseolus vulgaris) and spinach (Spinacia oleracea L.) were decreased with the increase in the concentration of sugar mill effluent, respectively when the effluents were used for fertigation. 
Table 9: ANOVA for effects of sugar mill effluent on metals in S. melongena

\begin{tabular}{|l|l|l|l|l|l|l|}
\hline Source & $\mathrm{Cd}$ & $\mathrm{Cr}$ & $\mathrm{Cu}$ & $\mathrm{Fe}$ & $\mathrm{Mn}$ & $\mathrm{Zn}$ \\
\hline Season $(\mathrm{S})$ & $*$ & $*$ & $*$ & $*$ & $*$ & $*$ \\
\hline SME concentration $(\mathrm{C})$ & $*$ & $*$ & $* *$ & $* *$ & $*$ & $* *$ \\
\hline$\underline{\text { Interaction }}$ & $*$ & $*$ & $* *$ & $* *$ & $*$ & $* *$ \\
\hline
\end{tabular}

SME- sugar mill effluent; .ns, *,** non-significant or significant at $\mathrm{P}<0.05$ or $\mathrm{P}<0.01$ level of ANOVA, respectively.

Table 10: ANOVA for effects of sugar mill effluent on biochemical components of $S$. melongena

\begin{tabular}{|l|l|l|l|l|}
\hline Source & $\begin{array}{l}\text { Crude } \\
\text { proteins }\end{array}$ & $\begin{array}{l}\text { Dietary } \\
\text { fiber }\end{array}$ & $\begin{array}{l}\text { Total } \\
\text { carbohydrates }\end{array}$ & $\begin{array}{l}\text { Total } \\
\text { sugar }\end{array}$ \\
\hline Season $(\mathrm{S})$ & $*$ & $*$ & $*$ & $*$ \\
\hline SME concentration $(\mathrm{C})$ & $*$ & $* *$ & $* *$ & $* *$ \\
\hline$\underline{\text { Interaction }}$ & $*$ & $* *$ & $* *$ & $* *$ \\
\hline $\mathrm{S} \times \mathrm{C}$ & & & & \\
\hline
\end{tabular}

SME- sugar mill effluent; ns, *, ** non-significant or significant at $\mathrm{P}<0.05$ or $\mathrm{P}<0.01$ level of ANOVA, respectively.

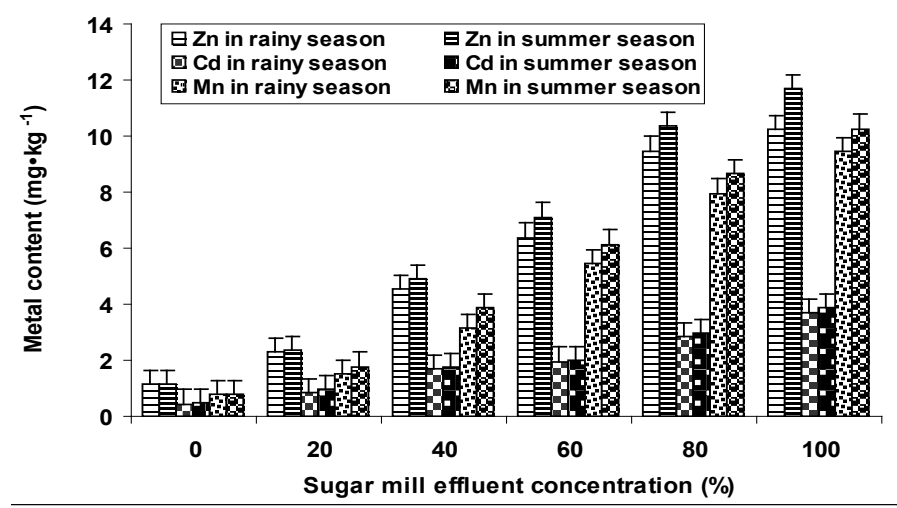

Figure 4: Contents of $\mathrm{Zn}, \mathrm{Cd}$ and $\mathrm{Mn}$ in $S$. melongena after irrigation with sugar mill effluent. Error bars are standard error of the mean.

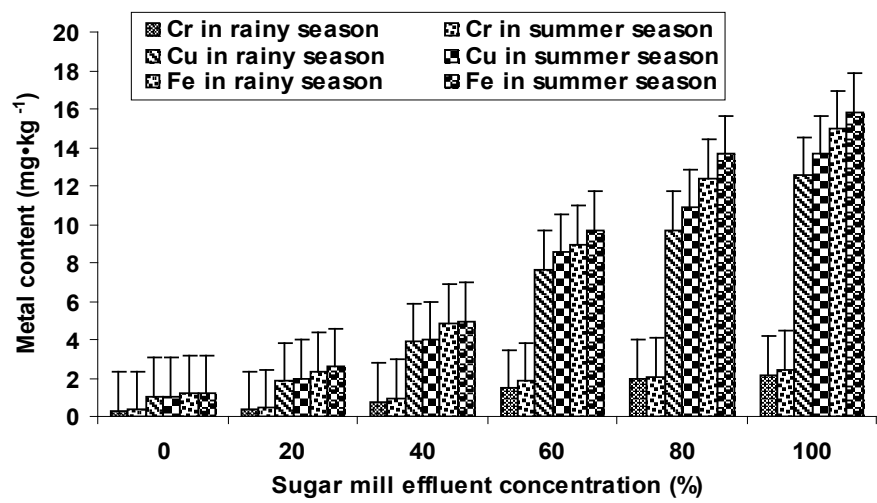

Figure 5: Contents of $\mathrm{Cr}, \mathrm{Cu}$ and $\mathrm{Fe}$ in $S$. melongena after irrigation with sugar mill effluent. Error bars are standard error of the mean.

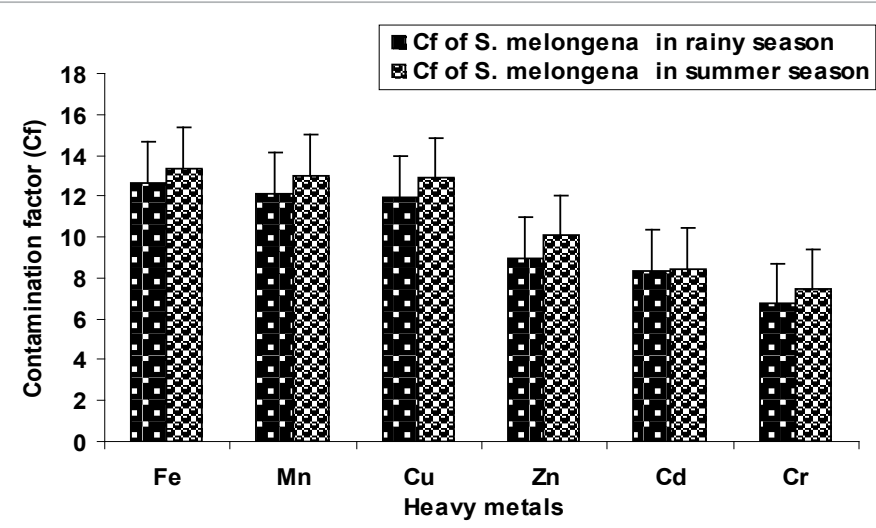

Figure 6: Contamination factor of heavy metals in S. melongena after irrigation with sugar mill effluent. Error bars are standard error of the mean.

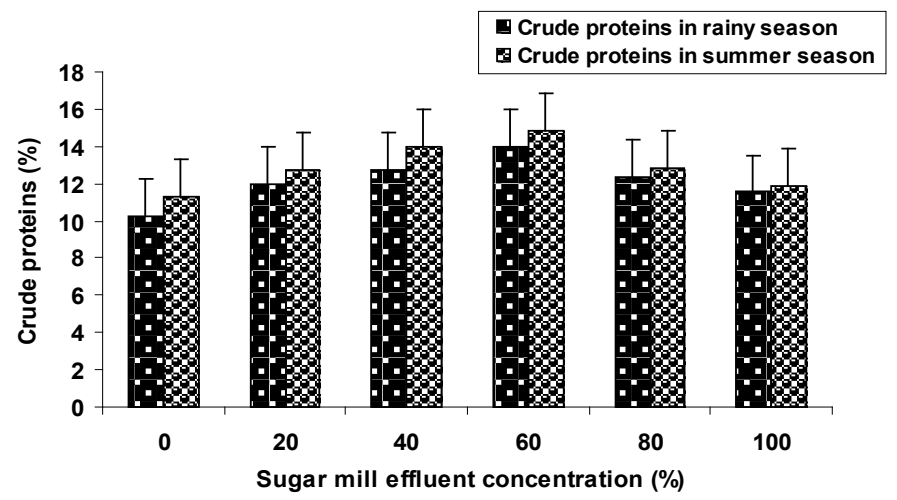

Figure 7: Crude proteins in S. melongena after irrigation with sugar mill effluent. Error bars are standard error of the mean.

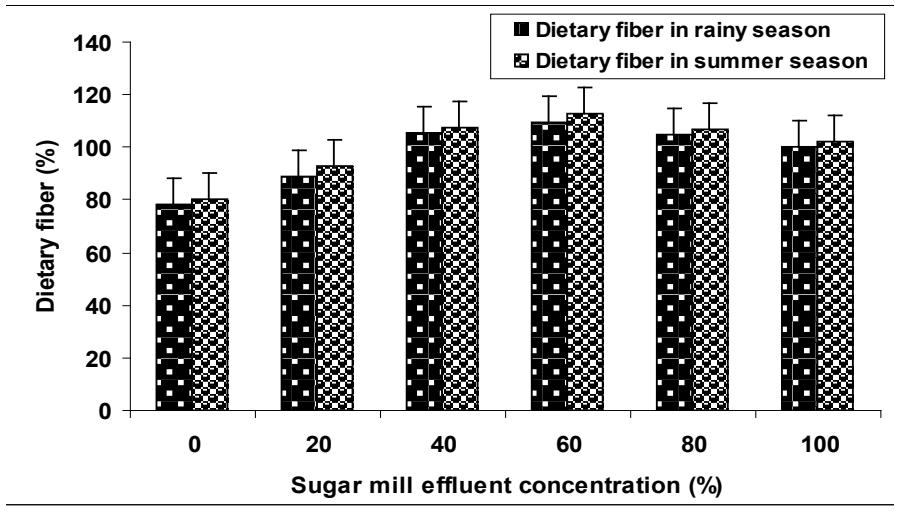

Figure 8: Dietary fiber in S. melongena after irrigation with sugar mill effluent. Error bars are standard error of the mean.

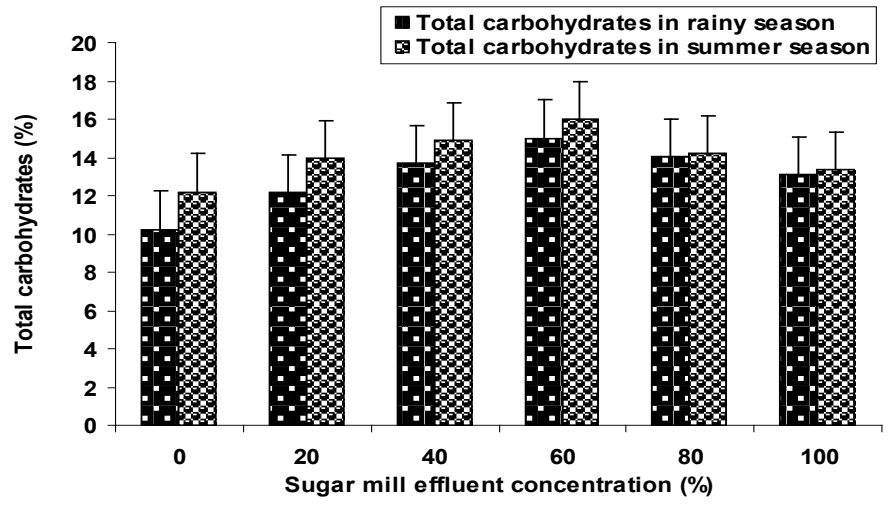

Figure 9: Total carbohydrates in $S$. melongena after irrigation with sugar mill effluent. Error bars are standard error of the mean 


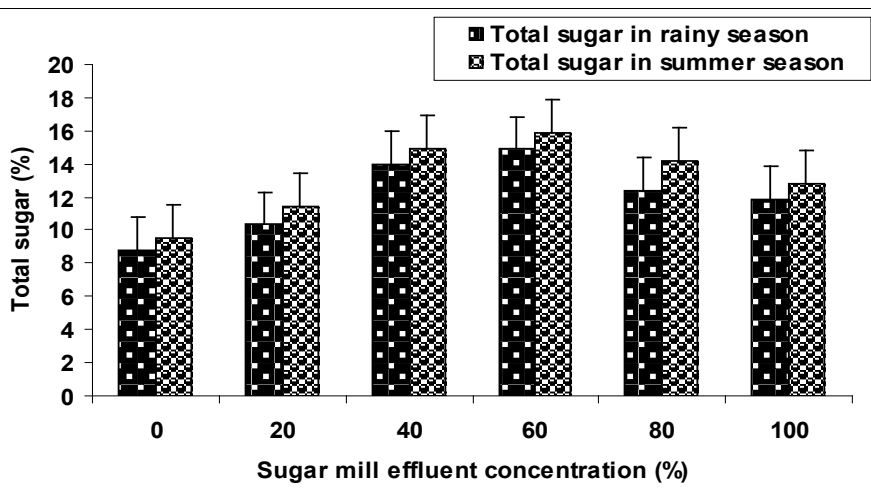

Figure 10: Total sugar in S. melongena after irrigation with sugar mill effluent. Error bars are standard error of the mean.

\section{Conclusion}

This study concluded that the concentrations of the sugar mill effluent viz. $0 \%$ (control), $20 \%, 40 \%, 60 \%, 80 \%$ and $100 \%$ significantly $(\mathrm{P}<0.05 / \mathrm{P}<0.01)$ affected the $\mathrm{EC}, \mathrm{pH}$, $\mathrm{OC}, \mathrm{Na}^{+}, \mathrm{K}^{+}, \mathrm{Ca}^{2+}, \mathrm{Mg}^{2+}, \mathrm{TKN}, \mathrm{PO}_{4}^{3-}, \mathrm{SO}_{4}^{2-}, \mathrm{Cd}, \mathrm{Cr}, \mathrm{Cu}, \mathrm{Fe}, \mathrm{Mn}$ and $\mathrm{Zn}$ of the soil used for the cultivation of $S$. melongena in both seasons. The agronomic performance of $S$. melongena was gradually increased from 20 to $60 \%$ and decreased from $80 \%$ to $100 \%$ concentrations of the sugar mill effluent in both the seasons compared to controls. The maximum agronomical attributes at vegetative growth stage and maturity stage of $S$. melongena along with biochemical components like crude proteins, dietary fiber, total carbohydrates and total sugar in S. melongena were found with $60 \%$ concentration of the sugar mill effluent in both seasons. The contamination factor $(\mathrm{Cf})$ of various metals were in the order of $\mathrm{Zn}>\mathrm{Mn}>\mathrm{Cd}>\mathrm{Cu}>\mathrm{Fe}>\mathrm{Cr}$ for the soil and $\mathrm{Fe}>\mathrm{Mn}>\mathrm{Cu}>\mathrm{Zn}>\mathrm{Cd}>\mathrm{Cr}$ for $S$. melongena in both seasons after irrigation with sugar mill effluent. It appears that sugar mill effluent can be used as a biofertigant after appropriate dilution (up to $60 \%$ ) to improve yield of $S$. melongena crop. Further studies on the agronomic growth and changes in biochemical composition of $S$. melongena after sugar mill effluent irrigation are required.

\section{Reference}

1) Ayyasamy, P.M., Yasodha, R., Rajakumar, S., et al. Impact of sugar factory effluent on the growth and biochemical characteristics of terrestrial and aquatic plants. (2008) Bull Environ Contam Toxicol 81(5): 449- 454.

2) Kumar, V. Sugar mill effluent utilization in the cultivation of maize (Zea mays L.) in two seasons. (2014a) J Waste Manag 12.

3) Baskaran, L., Sankar, G.K., Chidambaram, A.L.A., et al. Amelioration of sugar mill effluent polluted soil and its effect of green gram ( $\mathrm{Vi}$ gna radiata L.). (2009) Botany Research International 2(2): 131-135.

4) Baghel, R.S. Toxicity of distillery wastewater on seed germination, seedling growth and metabolism in Pisum sativum. (2008) Res J Environ Life Sci 1(1): 29-32.

5) Kumar, V., Chopra, A.K. Fertigational effects of sugar mill effluent on agronomical characteristics of high yield cultivar of sugarcane (Saccharum officinarum L.) in two Seasons. (2014d) Acta Adv Agr Sci 2(9): 17-39.

6) Chandra, R., Bhargava, R.N., Yadav, S., et al. Accumulation and distribution of toxic metals in wheat (Triticum aestivum L.) and Indian mustard (Brassica campestris L.) irrigated with distillery and tannery wastewaters. (2009) J Hazard Mater 162(2-3): 1514-1521.
7) Bharagava, R.N., Chandra, R., Rai, V., et al. Phytoextraction of trace elements and physiological changes in Indian mustard plants (Brassica nigra L.) grown in post methanated distillery effluent (PMDE) irrigated soil. (2008) Bioresour Technol 99(17): 8316-8324.

8) Kumar, V. Fertigation response of Abelmoschus esculentus L. (Okra) with sugar mill effluent in two different seasons. (2014) Int J Agr Sci Res 3(9): 164-180.

9) Kumar, V., Chopra, A.K. Ferti-irrigational impact of sugar mill effluent on agronomical characteristics of Phaseolus vulgaris (L.) in two seasons. (2014f) Environ Monit Assess 186(11): 7877-7892.

10) Muhammad, D., Khattak, R.A. Growth and nutrients concentrations of maize in effluent treated saline sodic soils. (2009) Soil Environ 28(2): 145-155.

11) Kumar, V., Chopra, A.K. Influence of sugar mill effluent on physico-chemical characteristics of soil at Haridwar (Uttarakhand), India. (2010) J Appl Nat Sci 2(2): 269-279.

12) Ezhilvannan, D., Sharavanan, P.S., Vijayaragavan, M., et al. Effect of sugar mill effluent on changes of growth and amino acid and protein contents of maize (Zea mays L.) plants. (2011) J Ecobiotechnol 3(7): 26-29.

13) E.J. Ferguson, "Heavy metals in plants. In: The heavy elements, Chemistry, Environmental Impact and Health Effects". (1990) Ferguson (Ed) Pergamon Press, Oxford, 7-30.

14) Paul, G.C., Bokhtiar, S.M., Rehman, H., et al. Efficacies of some organic fertilizers on sustainable sugar mill production in old Himalayan piedmont plain soil of Bangladesh. (2005) Pak Sug J 20(1): 2-5.

15) Kumar, V., Chopra, A.K. Alterations in physico-chemical characteristics of soil after irrigation with paper mill effluent. (2011) J Chem Pharm Res 3(6):7-22.

16) Hati, K.M., Biswas, A.K., Bandyopadhyay, K.K., et al. Soil properties and crop yields on a vertisol in India with application of distillery effluent. (2007) Soil and Tillage Research 92(1-2): 60-68.

17) Rath, P., Pradhan, G., Misra, M.K., et al. Effect of distillery spent wash (DSW) and fertilizer on growth and chlorophyll content of sugarcane (Saccharum officinarum L.) plant. (2011) Recent Research in Science and Technology 3(4): 169-176.

18) Kannan, A., Upreti, R.K. Influence of distillery effluent on germination and growth of mung bean (Vigna radiata, L.R. Wilczek) seeds. (2008) J Hazard Mater 153(1-2): 609-615.

19) Kumar, V., Chopra, A.K. Fertigation effect of distillery effluent on agronomical practices of Trigonella foenum-graecum L. (Fenugreek). (2012a) Environ Monit Assess 184(3): 1207-1219.

20) Kaushik, A., Kadyan, B.R., Kaushik, C.P., et al. Sugar mill effluent effects on growth, photosynthetic pigments and nutrient uptake in wheat seedlings in aqueous vs. soil medium. (1996) Water, Air Soil Pollut 87: 39-46.

21) Kisku, G.C., Barman, S.C., Bhargava, S.K., et al. Contamination of soil and plants potentially toxic elements irrigated with mixed industrial effluent and impact in the environment. (2000) Water, Air Soil Pollut 120: 121-137.

22) Kumar, V., Chopra, A.K. Response of sweet sorghum after fertigation with sugar mill effluent in two seasons. (2013) Sugar Tech 15(3): 285-299.

23) Nath, K., Singh, D., Sharma, Y.K., et al. Combinatorial effects of distillery and sugar factory effluents in crop plants. (2007) J Environ Biol 28(3): 577-582.

24) Kumar, V., Chopra, A.K. Enrichment and translocation of heavy metals in soil and Vicia faba L. (Faba bean) after fertigation with distillery effluent. (2013b) Int J Agr Policy Res 1(5): 131-141.

25) Kumar, V., Chopra, A.K. The effects of sugar mill effluent on hybrid cultivar of faba bean (Vicia faba L.) and soil properties. (2013c) Int J Biotechnol Res 1(6): 91-102.

26) Albino, J.W., Murugan, M. Effect of textile mill effluent on growth and germination of black gram - Vigna mungo (L.) Hepper. (2010) Int J Pharma Bio Sci 1(1): 1-7.

27) Kumar, V., Chopra, A.K. Accumulation and translocation of met- 
als in soil and different parts of French bean (Phaseolus vulgaris L.) amended with sewage sludge. (2014) Bull Environ Contam Toxicol 92(1): 103-108.

28) Kalaiselvi, P., Shenbagavalli, S. Mahimairaja, S., et al. Impact of post biomethanated distillery spent wash on seed germination and seedling growth of dry land crops. (2009) Madras Agr J 96: 331-334.

29) Krishna, K., Leelavathi, S. Toxicity of sugar factory effluent to germination, vigour index and chlorophyll content of paddy. (2002) Nature Environ Pollut Technol 1(3): 249-253.

30) Maliwal, G.L., Patel, K.P., Patel, K.C., et al. Pollution studies on sugar mill effluent, physico- chemical properties and toxic metals. (2004) Poll Res 14: 231-238.

31) Kumar, V., Chopra, A.K. Fertigational impact of sugar mill effluent on agronomical practices of Mung bean (Vigna radiata L.) in two seasons. (2014) Int J Agr Sci Res 3(4): 052-068.

32) Dar, S.A., Abdul, R., Wani, A.R., et al. Relationship between morphological characters of different brinjal genotypes and extent of infestation by L. orbonalis. (2014) Green Farming 6(5): 1-5.

33) Nunome, T., Ishiguro, K., Yoshida, T., et al. Mapping of fruit shape and color development traits in eggplant (Solanum melongena $\mathrm{L}$.) based on RAPD and AFLP markers. (2001) Breeding Sci 51(1): 19-26.

34) Prabhu, M., Natarajan, S., Veeraraganathatham, D., et al. The biochemical basis of shoot and fruit borer resistance in interspecific progenies of brinjal (Solanum melongena). (2009) Eur Asian J Biosci 3: 50-57.

35) Fukuoka, H., Yamaguchi, H., Nunome, T., et al. Accumulation, functional annotation, and comparative analysis of expressed sequence tags in eggplant (Solanum melongena L.), the third pole of the genus Solanum species after tomato and potato. (2010) Gene 450(1-2): 76-84. 36) Kumar, V., Chopra, A.K. Ferti-irrigational response of hybrid cultivar of Indian mustard (Brassica juncea L.) to distillery effluent in two seasons. (2014) Analyt Chem Lett 4(3): 190-206.

37) Sharma, R.K., Agrawal, M., Marshall, F., et al. Heavy metal contamination of soil and vegetables in suburban areas of Varanasi, India. (2007) Ecotoxicol Environ Saf 66(2): 258-266.

38) Vijayaragavan, M., Prabhahar, C., Sureshkumar, J., et al. Soil irrigation effect of sugar mill effluent on changes of growth and biochemical contents of Raphanus sativus L. (2011) Curr Bot 2(7): 9-13.

39) Kumar, V., Chopra, A.K., Srivastava, S., et al. Distribution, enrichment and accumulation of heavy metals in soil and Vigna mungo L. Hepper (Black gram) after irrigation with distillery wastewater. (2014) J Environ Health Sci 1(1): 1-8.

40) Mukhopadhyay, A., Mandal, A. Screening of brinjal (Solanum melongena) for resistance to major insect pests. (1994) Indian J Agri Sci 64(11): 798-803.

41) Kumar, V., Chopra, A.K. Fertigation with Agro-residue Based Paper Mill Effluent on a High Yield Spinach Variety. (2015) Int J Veg Sci 21(1): 69-97.

42) Yadav, R.K., Goyal, B., Sharma, R.K., et al. Post irrigation impact of domestic sewage effluent on composition of soils, crops and ground water-A case study. (2002) Environ Int 28(6): 481-486.

43) Sharma, B.L., Singh, S., Sharma, S., et al. Integerated response of effluent cake and urea on sugar mill in calcareous soil. (2002) Coope Sug 33(12): 1001-1004.
44) Sridhara, C.N., Kamala, C.T., Samuel, S., et al. Assessing risk of heavy metals from consuming food grown on sewage irrigated soils and food chain transfer. (2008) Ecotoxicol Environ Saf 69(3): 513-524. 45) Togay, N., Togay, Y., Doğan, Y., et al. Effects of municipal sewage effluent doses on the yield, some yield components and heavy metal concentration of dry bean (Phaseolus vulgaris L.). (2008) African J Biotechnol 7(17): 3026-3030.

46) Kumar, V., Chopra, A.K. Toxic element contamination in soil and spinach (Spinacia oleracea L.) after fertigation with sugar mill effluent. (2014) Int Res J Public Environ Health 1(4): 95-109.

47) Ramana, S., Biswas, A.K., Kundu, S., et al. Effect of distillery effluent on seed germination in some vegetable crops. (2002) Bioresour Technol 82(3): 273-275.

48) Kumar, V., Chopra, A.K. Pearl millet (Pennisetum Glaucum L.) response after ferti-Irrigation with sugar mill effluent in two seasons. (2014) Int J Recycl Org Waste Agr 3: 67.

49) Standard Methods for the Examination of Water and Wastewater. (2005) American Public Health Association, $21^{\text {st }}$ Ed, Washington, DC.

50) Chaturvedi, R.K., Sankar, K. Laboratory manual for the physico-chemical analysis of soil, water and plant. (2006) Wild life Institute of India, Dehradun 97.

51) Saxena, R., Diwakar, R. Biochemical Analysis of Chlorophyll Content of Brinjal Leaves. (2012) Vegetos-An Int J Plant Res 25(2): 83-85. 52) Kumar, V., Chopra, A.K. Response of high yield variety of Mung bean (Vigna radiata L.) after fertigation with distillery effluent in two seasons. (2013) Int J Biotechnol Res 1(7): 111-125.

53) Chopra, A.K., Srivastava, S., Kumar, V., et al. Agro-potentiality of distillery effluent on soil and agronomical characteristics of Abelmoschus esculentus L. (okra). (2012) Environ Monit Assess 185(8): 6635-6644.

54) Kumar, V., Chopra, A.K. Response of French bean to fertigation with wine from molasses distillery effluent in two seasons. (2014) Int J Veg Sci 20 (2): 104-123.

55) Rakkiyappan, P., Thangavelu, S., Malathi, R., et al. Effect of biocompost and enriched effluent on sugar mill yield and quality. (2001) Sugar Tech 3(3): 92-96.

56) Al-Mustafa, W.A., El-Shall A.A., Abdallah A.E., et al. Response of wheat to sewage effluent applied under two different moisture regimes. (1995) Exp Agric 31(3): 355-360.

57) Kumar, V., Chopra, A.K. Impact on physico-chemical characteristics of soil after irrigation with distillery effluent. (2011) Arch Appl Sci Res 3(4): 63-77.

58) Bokhtiar, S.M., Paul, G.C., Rashid M.A., et al. Effect of effluent and organic nitrogen on soil fertility and yield of sugar mill grown in high Ganges river flood plain soils of Bangladesh. (2001) Indian Sugar L1: 235-240.

59) BIS, In: "Indian Standards for drinking water- Specification (BIS 10500:1991)" retrieved on $20^{\text {th }}$ April, 2007 from (http:// www.bis.org. in/), 1991.

60) Joint FAO/WHO food standards programme codex committee on contaminants in foods. $5^{\text {th }}$ session. (2011) 64-89.
Ommega Online Publishers

Journal Title: Journal of Environment and Health Science (JEHS)

Journal Short Name: J Environ Health Sci
Journal ISSN: 2378-6841

E-mail: environmentalscience@ommegaonline.org

Website: www.ommegaonline.org 